\title{
Biomedical Laboratory: Its Safety and Risk Management
}

\section{$\operatorname{Tin} \operatorname{Tun}^{\dagger}$}

\author{
Singapore Association for Medical Laboratory Sciences (SAMLS), 637551, Singapore
}

\begin{abstract}
Biomedical laboratory is full of risks. Risk could be biological, chemical, radioactive, mechanical, physical, fire and electrical. All possible risks need to be identified, evaluated and controlled. A risk management system must be in place to prevent accident or loss of lives and to improve overall workplace safety and productivity. Safety in laboratory is a combination of appropriate risk management system, engineering controls and technical facilities, administrative controls and safety procedures and practices. Laboratory safety culture must be developed so that exposure to hazards for laboratory personnel, community and environment will be minimized or eliminated. In this review, importance of safety in a biomedical laboratory and risk management will be discussed.
\end{abstract}

Key Words: Risk management, Risk assessment, Hazard identification, Risk evaluation

\section{INTRODUCTION}

The golden rule for the "Safety in a laboratory" is simply everyone's responsibility. Safety cannot be performed by one person or one group or one department. All stakeholders need to be aware of safety procedures and practices and must abide by legal requirements (if any) and guidelines. Work entails various risks. The biomedical laboratory is a workplace where biological agents, infectious samples, toxic and corrosive chemicals, flammables, radioactive materials are handled. Many types of physical and mechanical instruments or equipment that are prone to accidents are also used. Risk Management (RM) is a part of work procedures to ensure risks are mitigated and properly communicated. All possible hazards and risks must be identified, assessed and evaluated. Implementation of adequate control measures is necessary to minimize or eradicate those risks.

\section{Safety in a Biomedical Laboratory}

Safety is the condition of being safe, free from danger, risk and injury; and to prevent any accident and loss. Answer to why we need a safe laboratory is simple - to keep us safe, healthy and alive so that we do our jobs peacefully. It also allows our families to know that we are safe at work. In creating a safe workplace, the management's commitment in safety and employee's involvement are important.

Safety in the laboratory is based on a combination of risk management system, provision of adequate facility and equipment, administrative controls and standard operating procedures and safety practices. Well-designed laboratory facility and equipment will minimize or eliminate exposures to hazardous agents for laboratory personnel, community and environment. Depending on risk levels of biological agents involved, biosafety level 2 (BSL 2), biosafety level 3 (BSL 3) and biosafety level 4 (BSL 4) facilities are estab-

* Received: July 19, 2017 / Accepted: August 7, 2017

${ }^{\dagger}$ Corresponding author: Tin Tun. Registered Biosafety Professional (RBP), IFBA Certified Professional in Biorisk Management, Singapore Association for Medical Laboratory Sciences (SAMLS), 637551, Singapore.

Tel: +65-6892-1801, e-mail: tintun64@gmail.com

(C) The Korean Society for Biomedical Laboratory Sciences. All rights reserved.

(c) This is an Open Access article distributed under the terms of the Creative Commons Attribution Non-Commercial License (http://creativecommons.org/licenses/by-nc/3.0/) which permits unrestricted non-commercial use, distribution, and reproduction in any medium, provided the original work is properly cited. 


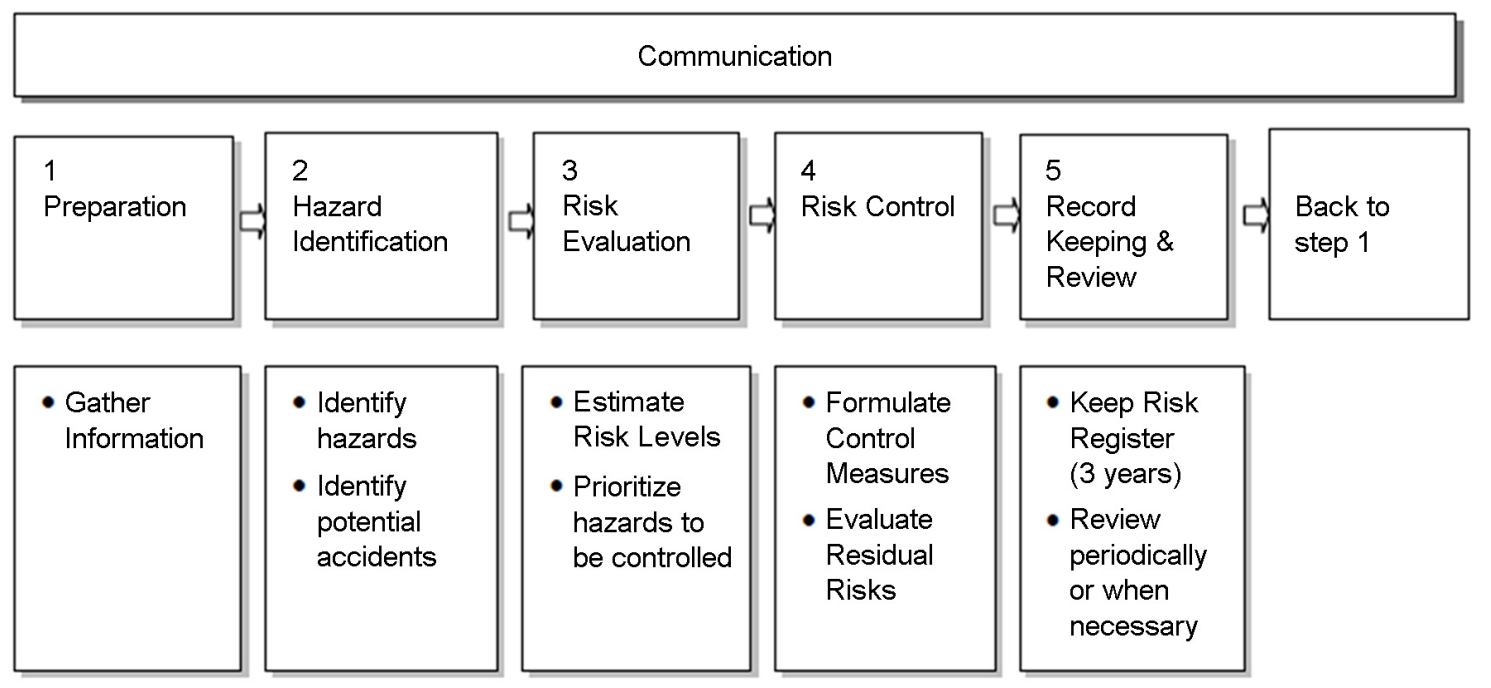

Fig. 1. Process in activity based - qualitative risk assessment method.

lished. The laboratory is not a place open to all. There must be a kind of control to access the area. Here administrative control measures are required. Other important administrative controls are to meet legislation requirements if any; to ensure that all laboratory users are competent in laboratory safety practices; appropriate training or sharing sessions are provided; and to keep necessary documents such as inventories of hazardous chemicals or biological agents in possession, audit and inspection reports, accident investigation records, etc.

Standard operating procedures (SOP) for safe use of laboratory equipment; safe work procedures, biosafety practices and procedures and emergency response plan must be in place. Proper use of personal protective equipment (PPE) such as laboratory coat, gloves, goggles, hair cover, shoes cover, mask or respirator as required is absolute necessary.

Risk management system is developed to prevent accident and loss of lives or property, to improve overall productivity. In Singapore, risk management system is required by the Workplace Safety and Health Act (Ministry of Manpower, 2006). Risk assessment (RA) is a legally required document and must be conducted in all work places including laboratory according to the Risk Management Regulations (Ministry of Manpower, 2006). It is the responsibility of the management (Head of Department) to ensure that the RM is being performed for all activities within the biomedical laboratory and department. Standard operating procedure on risk management must be available as an internal use only for staff members or laboratory users and updated on a regular basis. Development of the RA within any individual unit as a part of RM process is the responsibility of the principal investigator (PI), manager and the in-charge of that unit or workplace. RA document is project specific and conducted by a group or team based on feedbacks from stakeholders. It includes all activities with significant risks and is approved by the PI or the in-charge. Laboratory users are to apply appropriate control measures such as use of PPE and other protective means and to observe procedures prescribed in the risk assessments. Ultimately, it is everyone's responsibility to play a part for successful implementation of risk management.

\section{Risk Management}

In Singapore, the MOM adopts the "Activity Based Qualitative Evaluation Methodology" (Ministry of Manpower, 2006). Risk management involves assessment of risk associated; control measure to reduce risk; monitoring such risk at workplace and communicating the risk to the user. The process (Fig. 1) simply involves: 
Table 1. Severity table includes five different levels of risks

\begin{tabular}{|c|c|c|}
\hline Severity & Level & Criteria to consider \\
\hline Critical & 5 & $\begin{array}{l}\text { Fatal/ permanent injury; Poison/ Infection with unknown cure; Spill outside campus; } \\
>\$ 10 \text { million damage; }>1 \text { year downtime }\end{array}$ \\
\hline Very serious & 4 & $\begin{array}{l}30 \text { days MC/hospitalization; Infection with known cure; Spill outside building; } \\
>\$ 1 \text { million damage; }>3 \text { month downtime }\end{array}$ \\
\hline Serious & 3 & $\begin{array}{l}10 \text { days MC/hospitalization; Injury with } 1 \text { month recovery; Spill outside Lab/room; } \\
\$ 100,000 \text { damage; > } 1 \text { month downtime }\end{array}$ \\
\hline Marginal & 2 & $\begin{array}{l}3 \text { days MC; Very mild exposure; Spill outside workplace; }>\$ 10,000 \text { damage; } \\
>5 \text { days downtime }\end{array}$ \\
\hline Negligible & 1 & $\begin{array}{l}\text { First aid treatment only; mild / no exposure; Spill within workplace; }<\$ 5,000 \text { damage; } \\
\text { No significant downtime }\end{array}$ \\
\hline
\end{tabular}

- Breakdown of an experimental procedure or activity into steps

- Identification of the hazards or risks associated with the materials used and with process. Hazards associated with waste disposal, spill and other emergency procedures should also be considered

- Assess the frequency of occurrence and the severity of each hazard in context of the process and potential exposure.

- Determine the risks according to risk matrix.

- Controlling / reducing those risks to an acceptable level.

- Keep risk register - RA documents covering activities at workplace

- Communicating the risks to the users and review and feedback to monitor effectiveness over time.

Risk assessment (RA) record includes Hazard Identification, Risk Evaluation and Control measure using a $5 \times$ 5 risk matrix. A written description of the risk assessment for every activity must be developed at the workplace.

\section{Identify Hazards}

For each activity, the hazard or risk shall be determined. This is the most important part; the risk cannot be quantified or controlled if it is failed to identify. The hazards are based on but not limited to chemical, biological, radioactive, mechanical, thermal, ergonomic, electrical, etc. To assist the identification process, the reviewer should systematically review the activities from different points of view related to man, machine, material, method and environment for both the user and any other person at risk in the vicinity of the workplace where the activity is being carried out. Some examples of common hazards in biomedical laboratory that should be considered are:

- Biological - bacteria, virus, fungi, etc.

- Chemical - corrosive, toxic, flammable, etc.

- Radiation - radioactive materials, laser sources

- Mechanical - machine with moving parts, centrifuge, etc.

- Physical - excessive noise, heat, vibration, fire, explosion, etc.

- Electrical - frayed wires, electrical compliances

- Ergonomic - repetitive works, awkward postures

- Psychological - overwork, poor supervision, stress

\section{Risk Evaluation}

Risk Evaluation is the process of estimating severity and frequency of risk identified and calculating acceptable risk level. Risk prioritizing number (RPN) is the number assigned to an evaluated risk based on the likelihood and severity.

Severity (S) defines the degree or extent of an injury or harm caused by a hazard as a result of accident based. The extent of injury often varies but it is taken the worst possible likely to occur. The question is how badly it would occur to laboratory user (Table 1).

Likelihood (L) defines the probability or frequency of an event occurring. The question is what is the chance of an 
Table 2. Likelihood table includes five different levels of probability

\begin{tabular}{lcl}
\hline \hline Likelihood & Level & \multicolumn{1}{c}{ Occurrence criteria } \\
\hline Frequent & 5 & Likely to occur many times per year \\
Moderate & 4 & Likely to occur once a year \\
Occasional & 3 & Might occur once in 3 years \\
Remote & 2 & Might occur once in 5 year \\
Unlikely & 1 & Might occur once in 10 years \\
\hline
\end{tabular}

event happening (Table 2).

Risk levels or RPN is assessed by using levels of the severity and likelihood. Once severity and likelihood have been established, a $5 \times 5$ risk matrix is constructed to quantify the qualitative data for risk assessment (Fig. 2). Based on risk level obtained, the action and risk control measures are determined.

\begin{tabular}{|c|c|c|c|c|c|}
\hline & Critical & Very serious & Serious & Marginal & Negligible \\
\hline Frequent & $\begin{array}{c}25 \\
\text { Operation not } \\
\text { permissible }\end{array}$ & $\begin{array}{c}20 \\
\text { Operation not } \\
\text { permissible }\end{array}$ & $\begin{array}{c}15 \\
\text { High priority }\end{array}$ & $\begin{array}{c}10 \\
\text { Review at } \\
\text { appropriate time }\end{array}$ & $\begin{array}{c}5 \\
\text { Risk acceptable }\end{array}$ \\
\hline Moderate & $\begin{array}{l}20 \\
\text { Operation not } \\
\text { permissible }\end{array}$ & $\begin{array}{c}16 \\
\text { Operation not } \\
\text { permissible }\end{array}$ & $\begin{array}{c}12 \\
\text { High priority }\end{array}$ & $\begin{array}{c}8 \\
\text { Review at } \\
\text { appropriate time }\end{array}$ & $\begin{array}{c}4 \\
\text { Risk acceptable }\end{array}$ \\
\hline Occasional & $\begin{array}{c}15 \\
\text { High priority }\end{array}$ & $\begin{array}{c}12 \\
\text { High priority }\end{array}$ & $\begin{array}{c}9 \\
\text { Review at } \\
\text { appropriate time }\end{array}$ & $\begin{array}{c}6 \\
\text { Risk acceptable }\end{array}$ & $\begin{array}{c}3 \\
\text { Risk acceptable }\end{array}$ \\
\hline Remote & $\begin{array}{c}10 \\
\text { Review at } \\
\text { appropriate time }\end{array}$ & $\begin{array}{c}8 \\
\text { Review at } \\
\text { appropriate time }\end{array}$ & $\begin{array}{c}6 \\
\text { Risk acceptable }\end{array}$ & $\begin{array}{c}4 \\
\text { Risk acceptable }\end{array}$ & $\begin{array}{c}2 \\
\text { Risk acceptable }\end{array}$ \\
\hline Unlikely & $\begin{array}{c}5 \\
\text { Risk acceptable }\end{array}$ & $\begin{array}{c}4 \\
\text { Risk acceptable }\end{array}$ & $\begin{array}{c}3 \\
\text { Risk acceptable }\end{array}$ & $\begin{array}{c}2 \\
\text { Risk acceptable }\end{array}$ & $\begin{array}{c}1 \\
\text { Risk acceptable }\end{array}$ \\
\hline
\end{tabular}

Fig. 2. Risk matrix $(5 \times 5)$. RPN is calculated across the table. Risk level $1 \sim 6$ will be considered as low risk or acceptable risk or residual risk. Control measures are to apply for those higher risk levels.

Table 3. Action table. Appropriate control measures are taken to reduce risk level to acceptable or residual level

\begin{tabular}{|c|c|c|c|}
\hline Score & Risk level & Action & Hierarchy of control measures \\
\hline $16 \sim 25$ & High & $\begin{array}{l}\text { Operation not permissible } \\
\text { Stop operation and review controls }\end{array}$ & $\begin{array}{l}\text { Elimination / Substitution } \\
\text { Total removal of hazards. }\end{array}$ \\
\hline $12 \sim 15$ & Warning & $\begin{array}{l}\text { High priority remedial action } \\
\text { Implement additional controls immediately }\end{array}$ & $\begin{array}{l}\text { Physical Controls } \\
\text { Engineering controls are physical means that limit } \\
\text { the hazards. }\end{array}$ \\
\hline $8 \sim 10$ & Medium & $\begin{array}{l}\text { Remedial action at appropriate time } \\
\text { Proceed with care. Additional control advised }\end{array}$ & $\begin{array}{l}\text { Administrative controls } \\
\text { These reduce or eliminate exposure to a hazard by } \\
\text { adherence to procedures, instructions and training }\end{array}$ \\
\hline $1 \sim 6$ & Low & $\begin{array}{l}\text { Residual Risk / Risk acceptable } \\
\text { No imminent dangers. Frequent review in } \\
\text { change of procedure, material or environment }\end{array}$ & $\begin{array}{l}\text { Personal Protective Equipment (PPE) } \\
\text { This should be a minimum requirement after all } \\
\text { other control measures have been considered. The } \\
\text { success of this control critically depends on correct } \\
\text { choice, application and maintenance of protective } \\
\text { equipment, observation of SOPs, training and good } \\
\text { working practices. }\end{array}$ \\
\hline
\end{tabular}


Table 4. Example of risk assessment (RA) document

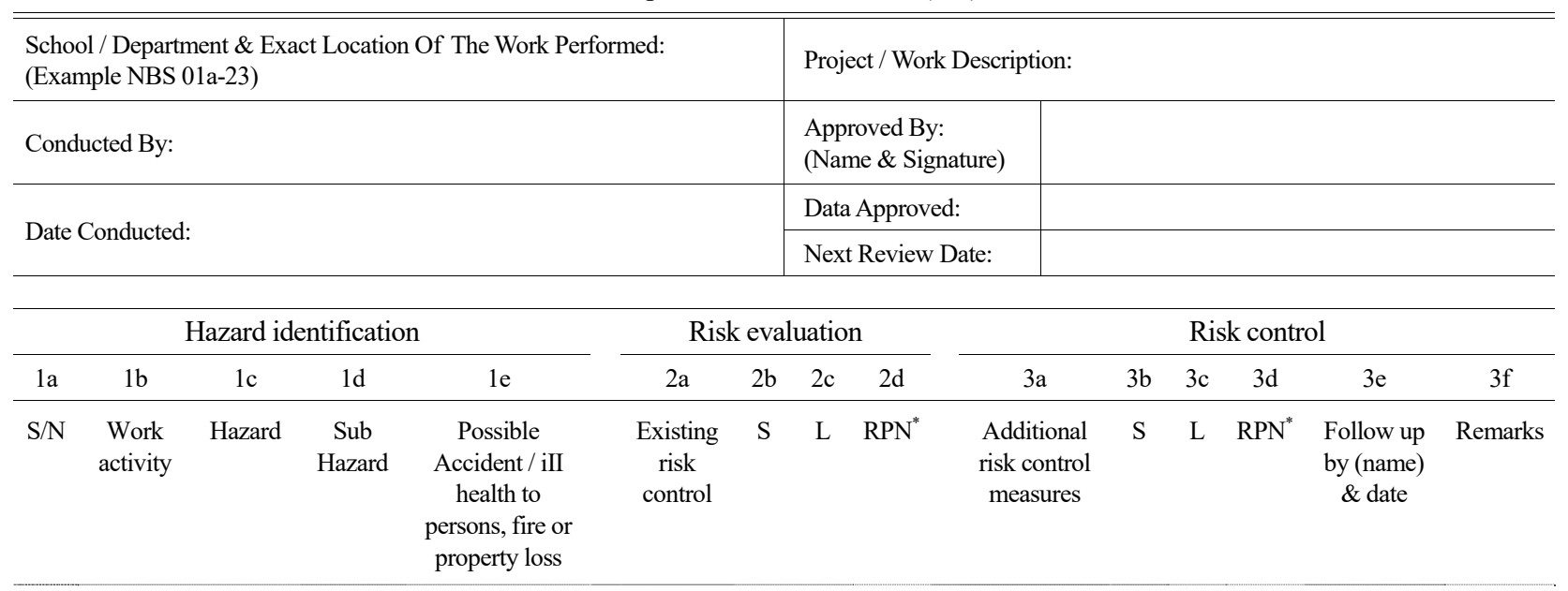

"RPN - Risk Prioritization Number

\section{Hierarchy of Control Measures}

It is essential to control risks usually by elimination or reduction "at the source". The control of hazards and reduction of risks can be accomplished by following the hierarchy of controls, step by step. If a risk cannot be controlled completely by engineering measures, it is necessary to protect the employees by administrative control or personal protection. These control measures are not mutually exclusive; engineering controls can be implemented together with administrative controls like training. Proper use of personal protective equipment is always necessary (Table 3). An example of the RA form for record keeping, training and reviewing purposes is shown in the Table 4.

\section{Conclusions}

Risk assessment is a legal document at workplace in Singapore. It should be taken more seriously for risky environment like laboratory. Assessments must be carried out and recorded for various activities for example, laboratory experiment, use of laboratory equipment, handling and storage of chemical, transportation of hazardous material, etc. Supporting documents such as safety data sheet (SDS) related to specific hazardous item, work procedure and work instruction should be included. Risk assessment needs to be reviewed and updated every 3 years or whenever changes are made. It will be a useful tool to have team members trained and communicated with risks at work.

\section{CONFLICT OF INTEREST}

This paper was presented in part at the $54^{\text {th }}$ KAMT Congress held in Yeosu City, Republic of Korea from May $26-29,2016$. The author declares that there is no conflict of interest.

\section{REFERENCES}

Ministry of Manpower (MOM), Singapore. "Workplace Safety and Health Act". 2006. http://www.mom.gov.sg/workplacesafety-and-health/workplace-safety-and-health-act

Ministry of Manpower (MOM), Singapore. "Workplace Safety and Health (Risk Management). Regulations". 2006. http:// 
www.mom.gov.sg/workplace-safety-and-health/safety-and-h

ealth-management-systems/risk-management
https://doi.org/10.15616/BSL.2017.23.3.155

Cite this article as: Tin Tun. Biomedical Laboratory: Its Safety and Risk Management. Biomedical Science Letters.

2017. 23: 155-160. 